\title{
ANALISIS PERBANDINGAN LIMA METODE IDENTIFIKASI BIOMETRIK SIDIK JARI DENGAN MENGGUNAKAN MATLAB 7.0
}

\section{COMPARISON ANALYSIS OF FIVE IDENTIFICATION METHODS FINGERPRINT BIOMETRIC USING MATLAB 7.0}

\author{
Jayanti Ardhani ${ }^{1}$, Widodo Ismanto ${ }^{2}$ \\ Program Studi Magister Manajemen Program Pascasarjana Universitas Riau Kepulauan \\ j.ardhani@gmail.com
}

\begin{abstract}
Abstrak
Seiring dengan pesatnya perkembangan teknologi, dibutuhkan sistem yang handal, dimana sistem berdasarkan kepemilikan dan pengetahuan sudah memiliki banyak kekurangan sehingga digunakan sistem biometrik sidik jari dimana password Anda adalah tubuh Anda, tidak perlu diingat ataupun terlupakan. Oleh karena itulah maka penulis melakukan analisis perbandingan lima metode identifikasi biometrik sidik jari dengan menggunakan Matlab 7.0. Tujuannya adalah untuk menghasilkan citra sidik jari yang lebih baik sehingga memudahkan proses identifikasi masalah yang berkaitan dengan proses pencitraan sidik jari.
\end{abstract}

Kata kunci: Analisis, Metode, Sidik Jari, Matlab 7.0

\begin{abstract}
In line with the rapid development of information technology, it is obviously needed to have a sophisticated system that can be trusted since the ordinary property and knowledge based systems have shown a lot of problematic issues (weaknesses), consequently the usage of individual fingerprint biometric technology is a better solution. This biometric system uses a human body part as a password that has neither to be remembered nor to be ignored. Based on the above facts, it is considered important to create this scientific writing entitled $A$ Comparative Analysis Of The Five Methods Of Fingerprints Biometric Identification Using Matlab 7.0. The objective is to gain a better result for facilitating problem identification processing inter-related with the fingerprint image processing.
\end{abstract}

Keywords: Analysis, Methods, Fingerprint, Matlab 7.0

\section{PENDAHULUAN}

Dewasa ini, seiring dengan pesatnya perkembangan kemajuan teknologi, dibutuhkan suatu metode yang handal untuk mengidentifikasi seseorang. Sistem identifikasi berdasarkan kepemilikan (possession based atau "what you have") dan sistem identifikasi berdasarkan pengetahuan (knowledge based atau "what you know") merupakan metode yang banyak digunakan sebagai alat identifikasi. Sistem identifikasi berdasarkan kepemilikan didasarkan pada suatu benda (token) yang dimiliki oleh seseorang, misalkan kartu kredit. Namun metode ini masih memiliki kelemahan dimana bila kartu tersebut hilang, orang yang tidak berwenang dapat menyalahgunakan kartu tersebut untuk kepentingan pribadinya sehingga merugikan pihak pemegang kartu. Sistem identifikasi berdasarkan pengetahuan menggunakan password sebagai media utamanya. Kelemahan dari sistem ini adalah apabila password terlalu pendek, sangat berisiko untuk dapat ditebak oleh pihak yang tidak bertanggung jawab, dan sebaliknya 
apabila password terlalu panjang maka akan mudah terlupa oleh pengguna. Untuk mengatasi masalah tersebut, digunakanlah metode lain yang lebih aman yaitu metode biometrika. Metode biometrika merupakan suatu metode karakteristik fisiologis dan karakteristik perilaku seperti sidik jari, wajah, suara, iris, retina mata, DNA serta tanda tangan. Identifikasi biometrik memiliki keunggulan dibandingkan dengan metode konvensional, yaitu tidak mudah dicuri atau digunakan oleh pihak yang tidak bertanggung jawab. Selain itu dengan metode biometrik, pengguna tidak perlu menghafal password ataupun membawa-bawa kartu, karena kunci utamanya melekat pada tubuh pengguna. Password Anda adalah tubuh Anda, hal ini dirasa cukup untuk mengungkapkan kelebihan dari metode biometrik.

Sidik jari manusia merupakan bukti materi yang amat penting. Tidak ada sidik jari yang identik di dunia ini sekalipun di antara dua saudara kembar yang 2 berasal dari satu indung telur. Hal ini disebabkan karena pola sidik jari yangterbentuk dalam embrio tidak pernah diturunkan. Bila jari seseorang mengalamiluka seperti tergores atau sobek, maka setelah sembuh sidik jari yang tergorestersebut akan kembali seperti sedia kala. Sidik jari seseorang tidak akan berubahselama hidupnya dan hanya akan berubah jika seseorang telah meninggal duniadan terjadi proses penguraian serta sebab-sebab lain seperti luka bakar. Dalamdunia sains pernah dikemukakan, jika ada 5 juta orang di bumi, kemungkinanmunculnya dua sidik jari manusia yang sama baru akan terjadi lagi 300 tahunkemudian (Piri,2003).

\section{Tujuan Penelitian}

Tujuan dari Penelitian ini adalah untuk menghasilkan pencitraan sidik jaritepatnya pada

bagian ibu jari yang lebih baik dengan menggunakan metode pendeteksian tepi sehingga memudahkan proses identifikasi masalah yang berkaitan dengan pencitraan biometrik sidik jari.

\section{Tinjauan Pustaka}

\section{Biometrika}

Badanmu adalah password-mu ungkapan inilah yang sering melekat pada istilah biometrika. Secara harfiah, biometrika atau biometrics berasal dari kata bio dan metrics. Bio berarti sesuatu yang hidup, dan metrics berarti mengukur. Sehingga dapat diartikan bahwa biometrika adalah mengukur karakteristik pembeda pada badan atau perilaku seseorang yang digunakan untuk melakukan pengenalan secara otomatis terhadap identitas orang tersebut, 
dengan membandingkan karakteristik yang sebelumnya telah disimpan pada suatu database. Pengertian pengenalan secara otomatis disini adalah dengan menggunakan teknologi (komputer), dimana pengenalan terhadap identitas seseorang dapat dilakukan secara realtime, tidak membutuhkan waktu berjam-jam bahkan sampai berhari-hari untuk proses pengenalan.

Karakteristik pembeda dapat dikelompokkan menjadi 2, yaitu karakteristik fisiologis atau fisik (physiological/physical characteristic) dan karakteristik perilaku (behavioral characteristic). Biometrika berdasarkan karakteristik fisiologis atau fisik menggunakan bagian-bagian fisik dari tubuh seseorang sebagai kode untuk pengenalan seperti DNA, telinga, jejak panas pada wajah, geometri tangan, pembuluh tangan, wajah, iris, telapak tangan, sidik jari, retina, telinga, gigi dan bau (komposisi kimia) dari keringat tubuh. Sedangkan biometrika berdasarkan karakteristik perilaku menggunakan perilaku seseorang sebagai kode unik untuk melakukan pengenalan, seperti gaya berjalan, hentakan tombol, tanda tangan dan suara. Beberapa persyaratan yang harus dipenuhi agar bagian-bagian tubuh atau perilaku manusia dapat digunakan sebagai biometrika, antara lain:

1. Universal (universality), artinya karakteristik yang dipilih harus dimiliki oleh setiap orang. Tahi lalat di dahi seseorang tidak dapat dijadikan biometrika karena tidak semua orang memiliki tahi lalat di dahi.

2. Membedakan (distinctivesness), artinya karakteristik yang dipilih memiliki kemampuan membedakan antara satu orang dengan orang lain. Berat dan tinggi badan seseorang tidak dapat digunakan sebagai biometrika karena banyak orang yang memiliki berat dan tinggi badan yang sama.

3. Permanen (permanence), artinya karakteristik yang dipilih tidak cepat berubah dalam periode waktu yang lama.

4. Kolektabilitas (collectability), artinya karakteristik yang dipilih mudah diperoleh dan dapat diukur secara kuantitatif.

5. Unjuk kerja (performance), artinya karakteristik yang dipilih dapat memberikan unjuk kerja bagus, baik dari segi akurasi maupun kecepatan, termasuk sumber daya yang dibutuhkan untuk memperolehnya.

6. Dapat diterima (acceptability), artinya masyarakat mau menerima karakteristik yang digunakan.

7. Tidak mudah dikelabui (circumvention), artinya karakteristik yang dipilih tidak mudah dikelabui dengan cara curang. 


\section{Sidik Jari}

Sidik jari adalah gurat-gurat yang terdapat di kulit ujung jari. Sidik jari berfungsi untuk memberi gaya gesek lebih besar agar jari dapat memegang benda $\neg$ benda lebih erat. Sistem pengamanan dengan menggunakan sidik jari sudah mulai dipergunakan di Amerika oleh seorang bernama E. Henry pada tahun 1901. Metode sidik jari digunakan Henry untuk melakukan identifikasi pekerja dalam rangka mengatasi pemberian upah ganda. Sistem Henry berasal dari pola ridge yang terpusat pola jari tangan, jari kaki, khusunya telunjuk. Metode yang klasik dari tinta dan menggulung jari pada suatu kartu cetakan menghasilkan suatu pola ridge yang unik bagi masing-masing digit individu. Hal ini telah dapat dipercaya membuktikan bahwa tidak ada dua individu mempunyai pola ridge serupa, pola ridge tidaklah bisa menerima warisan, pola ridge dibentuk embrio, pola ridge tidak pernah berubah dalam hidup, dan hanya setelah kematian dapat berubah sebagai hasil pembusukan.

Dalam hidup, pola ridge hanya diubah secara kebetulan akibat luka-luka, terbakar, penyakit atau penyebab lain yang tidak wajar. Identifikasi dari sidik jari memerlukan pembedaan tentang bentuk keliling papillary ridge tak terputuskan yang diikuti oleh pemetaan tentang gangguan atau tanda anatomic ridge yang sama. Sistem biometrika sidik jari merupakan sistem autentikasi berbasis biometrika yang paling banyak digunakan saat ini karena memiliki tingkat akurasi yang tinggi dan mudah diterapkan.

\section{METODOLOGI}

Penulisan ini menggunakan metode studi pustaka yaitu dengan mempelajari buku-buku, jurnal penulisan serta dari situs-situs internet yang dapatmembantu dan berhubungan dengan penulisan.

\section{Rancangan Penelitian}

Berikut akan dijelaskan algoritma dari proses deteksi tepi sidik jari :

1. Proses didahului dengan pembacaan ke-10 sampel citra asli sidik jariyang berasal dari 10 individu yang berbeda.

2. Merubah tipe data citra dari uint 8 menjadi logical dengan proses biner

3. Melakukan pendeteksian tepi terhadap citra asli dengan metode deteksitepi antara lain Sobel, Canny, Prewitt, Roberts, serta Log

4. Analisis hasil pendeteksian tepi menggunakan PSNR (Peak Signal toNoise Ratio) 


\section{Prosedur Pengumpulan Datan}

Data penelitian adalah data sekunder, dibatasi pada biometrik sidik jari, tepatnya bagian ibu jari sebelahkiri. (URL: http://www.biometrics.org/html/research.html) merupakan sumbersidik jari yang telah jadi untuk digunakan dalam Penelitian ini.Selanjutnya dilakukan metode identifikasi diantaranya adalah metodependeteksian tepi Sobel, Canny, Prewitt, Roberts, serta Log. Dimana citra aslidirubah menjadi logical melalui proses biner, serta dianalisis denganmenggunakan PSNR (Peak Signal to Noise Ratio) dengan menggunakan sistemoperasi Matlab 7.0 dari Mathwork Inc.

\section{Teknik Analisis Data}

Analisis data dilakukan dengan menggunakan sistemoperasi Matlab 7.0 dari Mathwork Inc.

\section{PEMBAHASAN}

Pengolahan citra (image processing) adalah bidang tersendiri yang sudah cukup berkembang sejak orang mengerti bahwa komputer tidak hanya dapat menangani data teks, tetapi juga data citra. Pengolahan citra merupakan proses pengolahan dan analisis citra yang banyak melibatkan persepsi visual. Proses ini mempunyai ciri data masukan dan informasi keluaran yang berbentuk citra.

Objek citra yang digunakan adalah citra sidik jari, tepatnya pada bagian ibu jari. Ibu jari dipilih sebagai objek karena keunikannya, serta tidak akan mengalami perubahan kecuali dikarenakan adanya penyebab lain seperti lukaluka, terbakar, penyakit, ataupun penyebab lain yang tidak wajar. Ibu jari menghasilkan gambaran yang paling baik dan jelas jika dibandingkan dengan bagian jari lainnya, semua itu tampak dari pola loop, whorl, serta arch (Pola Pappilary Ridge) sehingga dipilihlah ibu jari sebagai objek pada Penelitian ini. Setiap individu memiliki dua buah ibu jari yaitu ibu jari sebelah kanan dan ibu jari sebelah kiri. Pada penulisan ini, citra ibu jari yang digunakan adalah bagian sebelah kiri, hal ini dikarenakan ibu jari sebelah kiri bersifat lebih pasif dibandingkan dengan ibu jari sebelah kanan. Pasif disini dapat diartikan bahwa ibu jari sebelah kiri lebih jarang digunakan dibandingkan dengan ibu jari sebelah kanan, dimana sebagian besar aktifitas keseharian ibu jari sebelah kanan bertindak lebih aktif dibandingkan dengan ibu jari sebelah kiri. Sehingga pola-pola yang ada pada sidik jari sebelah kiri akan senantiasa terjaga, walaupun tidak akan berubah sampai seorang individu meninggal nanti.

Pada Penelitian ini digunakan ibu jari sebelah kiri, semakin banyak sampel ibu jari 
yang digunakan, maka akan semakin tampak hasil terbaik dari setiap metode pendeteksian tepi yang diujikan. Diambil sampel dari 10 individu yang berbeda, dimana citra ibu jari berasal dari citra yang telah jadi (http://bias.csr.unibo.it/fvc2006/databases.asp). Citra ibu jari adalah sidik jari asli dimana berasal dari ibu jari sebelah kiri 10 individu yang telah didaftarkan sebelumnya dengan menggunakan sensor pendeteksian sidik jari dimana prosesnya adalah ibu jari sebelah kiri ditempelkan pada suatu alat sensor khusus, sehingga akan dihasilkan citra ibu jari yang sesuai dengan kebutuhan pada Penelitian ini, yaitu citra ibu jari yang baik, jelas polanya, serta tidak rusak. Sepuluh citra ibu jari asli akan dianalisis dengan menggunakan metode pendeteksian tepi sehingga dihasilkan citra baru, yaitu citra ibu jari hasil pendeteksian. Keseluruhan citra asli ibu jari berdimensi 640 x 480 dan bertipe .jpeg (Joint Photographic Experts Group) serta berukuran (size) 300 KB.

\section{Pengambilan Gambar}

Seluruh citra ibu jari asli disimpan pada Current Directory Window, mula-mula dilakukan pembacaan citra ibu jari asli yang bertipe data uint8 yaitu data citra yang direpresentasikan array berukuran $\mathrm{m} \times \mathrm{n}$ bernilai antara 0 atau 1, dimana pada analisis ini semua citra dirubah menjadi data logical dimana data citra dapat dibandingkan dengan citra lain sehingga menghasilkan nilai yang logik. Dapat dilihat pada gambar 1 yang menampilkan 2 gambar dari 10 sampel ibu jari asli yang digunakan.

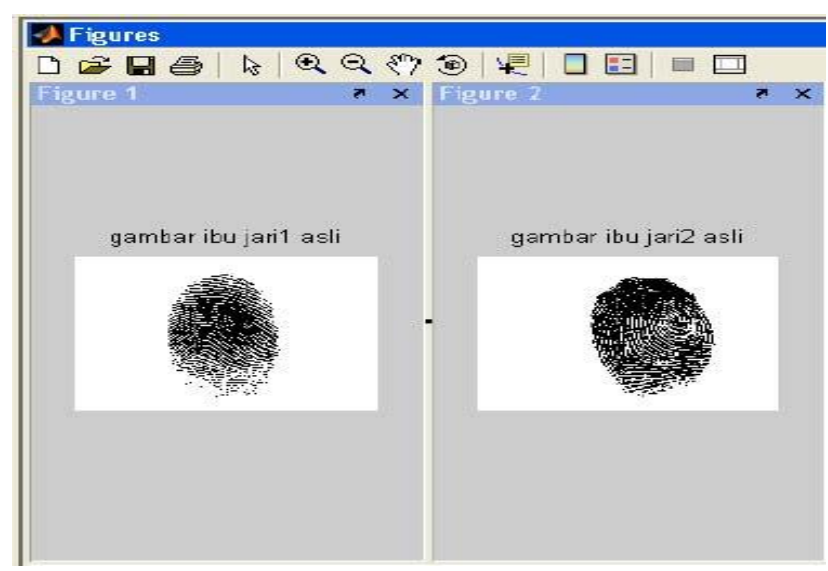

Gambar 1. Sampel Ibu Jari

\section{Pendeteksian Tepi}

Edge atau tepi dipandang sebagai lokasi piksel dimana terdapat nilai perbedaan intensitas citra secara ekstrem. Deteksi tepi berfungsi untuk mengidentifikasikan garis batas dari suatu objek yang terdapat pada citra ibu jari. Edge detector bekerja dengan cara mengidentifikasikan dan menonjolkan lokasi piksel yang memiliki karakteristik tersebut. 
Dalam Penelitian ini digunakan 5 (lima) buah metode pendeteksian tepi pada sampel $10 \mathrm{ibu}$ jari asli dari 10 individu yang berbeda, yaitu metode Sobel, Canny, Prewitt, Roberts, serta $\log$.

Metode Canny merupakan metode modern yang tidak memiliki operator khusus, namun metode Canny terdiri dari beberapa langkah khusus. Metode Canny akan mendeteksi tepi dengan mencari nilai gradient maksimal lokal dari citra asli ibu jari dan menggunakan dua pengambangan (thresholds) yang berguna untuk mendeteksi tepian yang terlihat jelas dan tepian yang kurang jelas atau lemah. Metode Canny lebih utama akan mendeteksi tepian yang kurang jelas. Hasil pendeteksian dengan metode Canny dapat dilihat pada gambar 2.

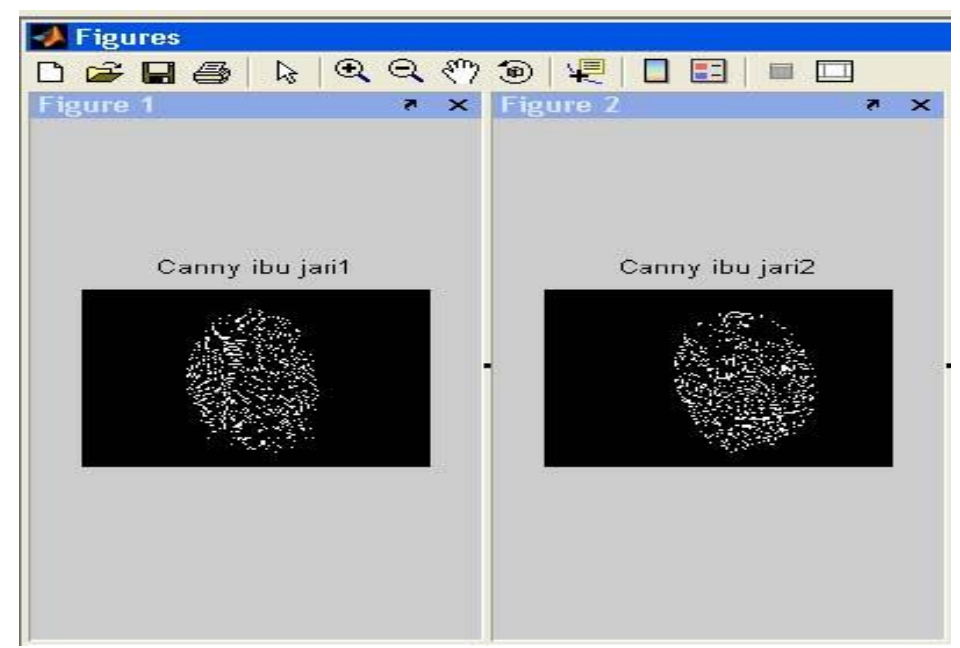

Gambar 2. Hasil Pendeteksian dengan Metode Canny

Metode pendeteksian tepi menggunakan nilai tengah yang dinotasikan dengan $\mathrm{h}(2,2)$ bersumber dari piksel citra asli ibu jari1 yang bernilai 1, maka nilai piksel-piksel citra asli ibu jari1 pada gambar 3 .

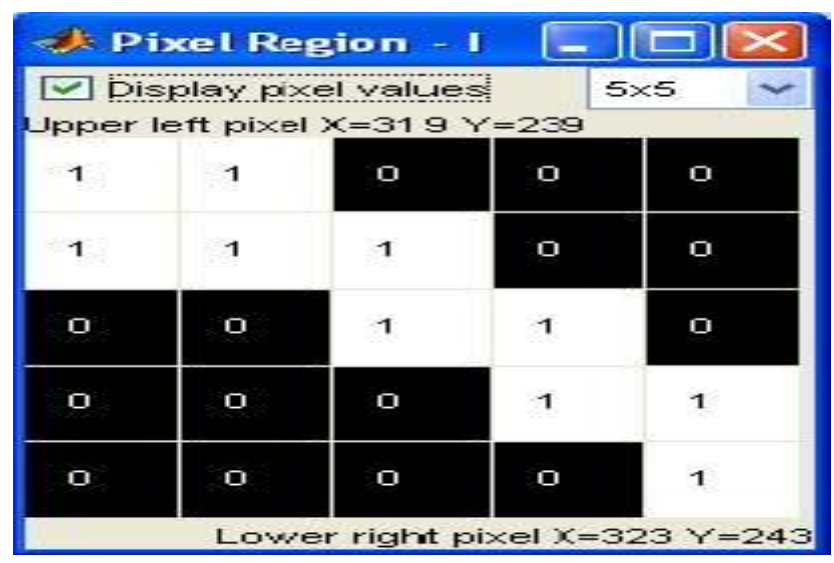

Gambar 3. Piksel asli ibu jari

Piksel-piksel pada citra asli ibu jari akan di operasikan pada setiap metode untuk mencari 
hasil penjumlahan, nilai maksimum, serta nilai rata-rata yang akan dimasukkan ke dalam matriks setiap metode pendeteksian tepi.

$$
\begin{aligned}
& \mathrm{K} 0(\mathrm{x}, \mathrm{y})=(|\mathrm{K} 1(\mathrm{x}, \mathrm{y})|+|\mathrm{K} 2(\mathrm{x}, \mathrm{y})|) \\
& \mathrm{K} 0(\mathrm{x}, \mathrm{y})=\max (|\mathrm{K} 1(\mathrm{x}, \mathrm{y})|,|\mathrm{K} 2(\mathrm{x}, \mathrm{y})|) \\
& \mathrm{K} 0(\mathrm{x}, \mathrm{y})=(|\mathrm{K} 1(\mathrm{x}, \mathrm{y})|+|\mathrm{K} 2(\mathrm{x}, \mathrm{y})|) / 2 \\
& \mathrm{~K} 0(\mathrm{x}, \mathrm{y})=\longdiv { \mathrm { K } 1 ( \mathrm { x } , \mathrm { y } ) * \mathrm { K } 1 ( \mathrm { x } , \mathrm { y } ) + \mathrm { K } 2 ( \mathrm { x } , \mathrm { y } ) * \mathrm { K } 2 ( \mathrm { x } , \mathrm { y } ) \ldots \ldots }
\end{aligned}
$$

Keterangan : K0 adalah hasil dari pencarian tiap nilai piksel

K1 adalah nilai piksel horizontal

K2 adalah nilai piksel vertikal

$\mathrm{x}$ adalah nilai matriks dari setiap metode pendeteksian tepi

y adalah nilai piksel dari citra asli ibu jari1

Metode Sobel melakukan perhitungan secara 2D terhadap suatu ruang di dalam sebuah gambar dengan harapan akan tampak daerah-daerah bernilai tinggi pada gambar tersebut yang merupakan deteksi tepi dari suatu gambaran, biasanya digunakan untuk mencari gradient dari masing-masing piksel gambar input. Metode Sobel menempatkan penekanan atau pembobotan pada piksel-piksel yang lebih dekat dengan titik pusat jendela. Dengan demikian pengaruh piksel-piksel tetangga akan berbeda sesuai dengan letaknya terhadap titik di mana gradien dihitung.

Metode Sobel horizontal Metode Sobel vertikal

\begin{tabular}{|l|l|l|}
\hline-1 & 0 & 1 \\
\hline-2 & 0 & 2 \\
\hline-1 & 0 & 1 \\
\hline
\end{tabular}

\begin{tabular}{|c|c|c|}
\hline 1 & 2 & 1 \\
\hline 0 & 0 & 0 \\
\hline-1 & -2 & -1 \\
\hline
\end{tabular}

Horizontal $=\mathrm{K} 1(\mathrm{x}, \mathrm{y})=|(-1 * 1)+(-2 * 0)+(-1 * 0)+(1 * 0)+(2 * 1)+(1 * 1)|=2$

Vertikal $=\mathrm{K} 2(\mathrm{x}, \mathrm{y})=|(1 * 1)+(2 * 1)+(1 * 0)+(-1 * 0)+(2 * 0)+(-1 * 1)|=2$

Maka $\mathrm{h}(2,2)$ bila menggunakan : $\mathrm{K} 0(\mathrm{x}, \mathrm{y})=(|\mathrm{K} 1(\mathrm{x}, \mathrm{y})|+|\mathrm{K} 2(\mathrm{x}, \mathrm{y})|)=2+2=4$

$\mathrm{K} 0(\mathrm{x}, \mathrm{y})=\max (|\mathrm{K} 1(\mathrm{x}, \mathrm{y})|,|\mathrm{K} 2(\mathrm{x}, \mathrm{y})|)=2 \mathrm{~K} 0(\mathrm{x}, \mathrm{y})=(|\mathrm{K} 1(\mathrm{x}, \mathrm{y})|+|\mathrm{K} 2(\mathrm{x}, \mathrm{y})|) / 2=(2+2) / 2$ $=2$

$\mathrm{K} 0(\mathrm{x}, \mathrm{y})=\longdiv { \mathrm { K } 1 ( \mathrm { x } , \mathrm { y } ) ^ { * } \mathrm { K } 1 ( \mathrm { x } , \mathrm { y } ) + \mathrm { K } 2 ( \mathrm { x } , \mathrm { y } ) } { } ^ { * } \mathrm { K } 2 ( \mathrm { x } , \mathrm { y } )$ 


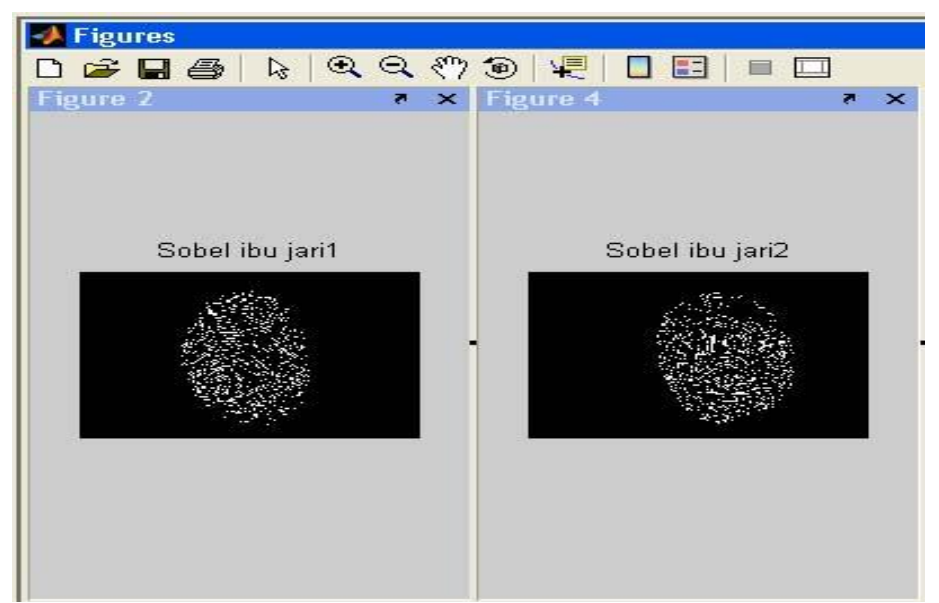

Gambar 4. Hasil Pendeteksian dengan Metode Sobel

Metode Prewitt menggunakan persamaan yang sama dengan Sobel, kecuali konstanta c bernilai sama dengan 1. Metode Prewitt tidak meletakkan penekanan pada piksel-piksel yang lebih dekat dengan titik pusat dari jendela, sehingga keseluruhan piksel mempunyai pengaruh yang sama terhadap perhitungan gradient pada titik pusat jendela. Metode Prewitt horizontal Metode Prewitt vertical

\begin{tabular}{|l|l|l|}
\hline-1 & 0 & 1 \\
\hline-1 & 0 & 1 \\
\hline-1 & 0 & 1 \\
\hline
\end{tabular}

\begin{tabular}{|l|l|l|}
\hline 1 & 1 & 1 \\
\hline 0 & 0 & 0 \\
\hline-1 & -1 & -1 \\
\hline
\end{tabular}

Horizontal $=\mathrm{K} 1(\mathrm{x}, \mathrm{y})=|(-1 * 1)+(-1 * 0)+(-1 * 0)+(1 * 0)+(1 * 1)+(1 * 1)|=1$

Vertikal $=\mathrm{K} 2(\mathrm{x}, \mathrm{y})=|(1 * 1)+(1 * 1)+(1 * 0)+(-1 * 0)+(-1 * 0)+(-1 * 1)|=1$

Maka $\mathrm{h}(2,2)$ bila menggunakan $: \mathrm{K} 0(\mathrm{x}, \mathrm{y})=(|\mathrm{K} 1(\mathrm{x}, \mathrm{y})|+|\mathrm{K} 2(\mathrm{x}, \mathrm{y})|)=1+1=2$

$\mathrm{K} 0(\mathrm{x}, \mathrm{y})=\max (|\mathrm{K} 1(\mathrm{x}, \mathrm{y})|,|\mathrm{K} 2(\mathrm{x}, \mathrm{y})|)=1 \mathrm{~K} 0(\mathrm{x}, \mathrm{y})=(|\mathrm{K} 1(\mathrm{x}, \mathrm{y})|+|\mathrm{K} 2(\mathrm{x}, \mathrm{y})|) / 2=(1+1) / 2$

$=1$

$\mathrm{K} 0(\mathrm{x}, \mathrm{y})=\longdiv { \mathrm { K } 1 ( \mathrm { x } , \mathrm { y } ) * \mathrm { K } 1 ( \mathrm { x } , \mathrm { y } ) + \mathrm { K } 2 ( \mathrm { x } , \mathrm { y } ) * \mathrm { K } 2 ( \mathrm { x } , \mathrm { y } ) }$ 


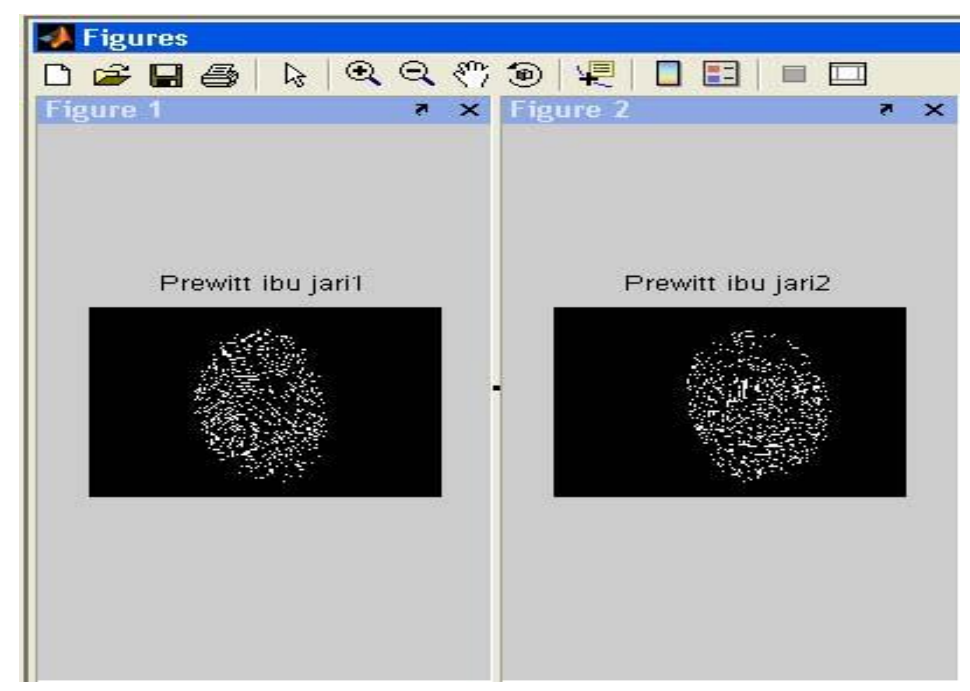

Gambar 5. Hasil Pendeteksian dengan Metode Prewitt

Metode Roberts menggunakan diagonal untuk mendeteksi tepi citra asli ibu jari dibandingkan dengan arah horizontal maupun arah vertikal, sehingga perbedaan yang terletak pada sisi-sisi miring obyek akan terdeteksi dengan baik. Metode Roberts menggunakan jendela dengan ukuran $2 \times 2$ piksel.

Metode Roberts diagonal 1 Metode Roberts diagonal 2
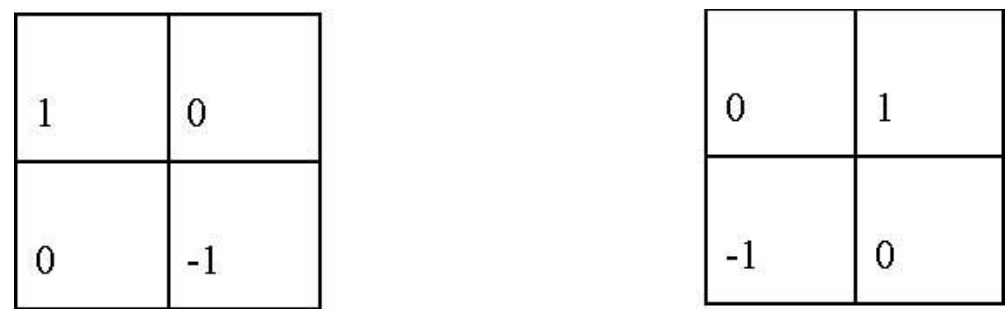

Diagonal1 $=\mathrm{K} 1(\mathrm{x}, \mathrm{y})=|(1 * 1)+(0 * 0)+(0 * 0)+(-1 * 1)|=0$

Diagonal2 $=\mathrm{K} 2(\mathrm{x}, \mathrm{y})=|(0 * 1)+(1 * 0)+(-1 * 0)+(0 * 1)|=0$

Maka $\mathrm{h}(2,2)$ bila menggunakan : $\mathrm{K} 0(\mathrm{x}, \mathrm{y})=(|\mathrm{K} 1(\mathrm{x}, \mathrm{y})|+|\mathrm{K} 2(\mathrm{x}, \mathrm{y})|)=0+0=0$

$\mathrm{K} 0(\mathrm{x}, \mathrm{y})=\max (|\mathrm{K} 1(\mathrm{x}, \mathrm{y})|,|\mathrm{K} 2(\mathrm{x}, \mathrm{y})|)=0 \mathrm{~K} 0(\mathrm{x}, \mathrm{y})=(|\mathrm{K} 1(\mathrm{x}, \mathrm{y})|+|\mathrm{K} 2(\mathrm{x}, \mathrm{y})|) / 2=(0+0) / 2$ $=0$

$$
\mathrm{K} 0(\mathrm{x}, \mathrm{y})=\longdiv { \mathrm { K } 1 ( \mathrm { x } , \mathrm { y } ) ^ { * } \mathrm { K } 1 ( \mathrm { x } , \mathrm { y } ) + \mathrm { K } 2 ( \mathrm { x } , \mathrm { y } ) * \mathrm { K } 2 ( \mathrm { x } , \mathrm { y } ) }
$$




$$
=\sqrt{\left(0^{*} 0\right)+\left(0^{*} 0\right)}=0
$$

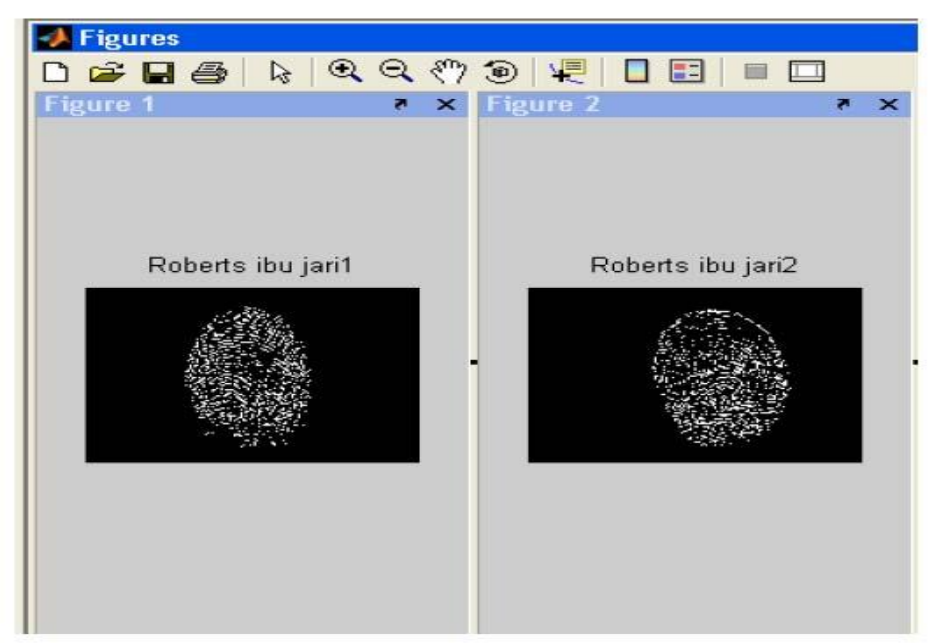

Gambar 6. Hasil Pendeteksian dengan Metode Roberts

Metode Log merupakan metode pendeteksian tepi dengan operator turunan kedua, disebut juga metode Laplace. Pendeteksian tepi dengan metode Log lebih akurat khususnya pada tepi yang curam. Pada tepi yang curam, turunan keduanya memiliki zero crossing (persilangan nol), yaitu titik dimana terdapat pergantian tanda nilai turunan kedua, sedangkan pada tepi yang landai tidak terdapat persilangan nol. Hasil pendeteksian dengan metode Log dapat dilihat pada gambar 7 .

\section{Metode Log}

\begin{tabular}{|l|l|l|}
\hline-1 & -1 & -1 \\
\hline-1 & 8 & -1 \\
\hline-1 & -1 & -1 \\
\hline
\end{tabular}

$\mathrm{K} 1(\mathrm{x}, \mathrm{y})=\left|\left(-1^{*} 1\right)+(-1 * 1)+(-1 * 0)+(-1 * 0)+\left(8^{*} 1\right)+(-1 * 1)+(-1 * 0)+(-1 * 0)+(-1 * 1)\right|$ $=4$ 


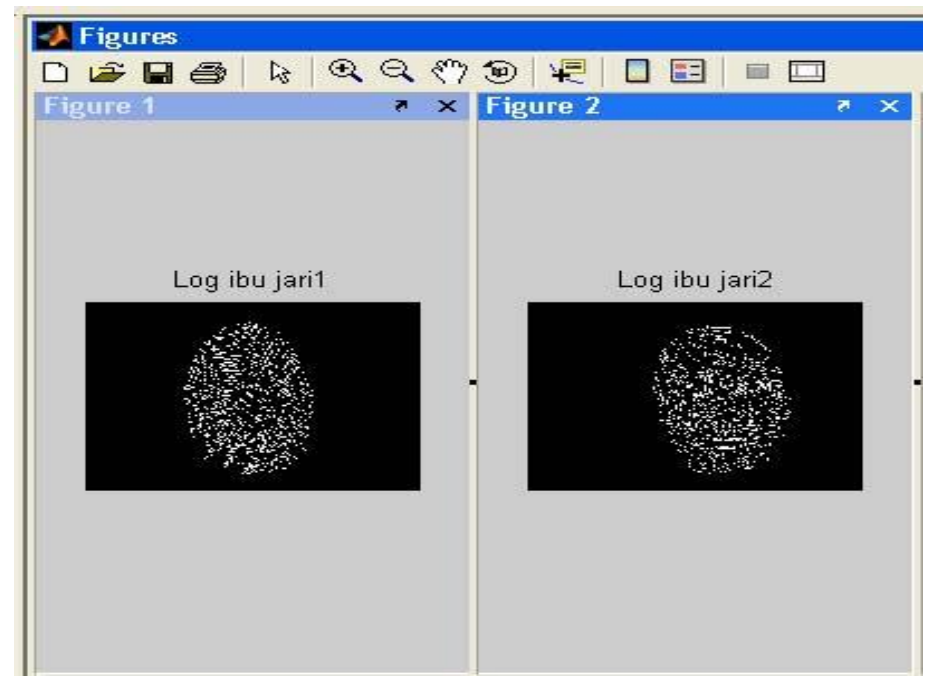

Gambar 7. Hasil Pendeteksian dengan Metode Log

\section{Implementasi}

Pada awal program dijalankan akan dilakukan proses pembersihan layar Command Window dengan menggunakan perintah clc dan mengosongkan memori Matlab dari semua variabel yang pernah diolah dengan clear sebelum melakukan proses selanjutnya

clc;

clear all; Sepuluh citra sidik jari akan dibaca program dengan menggunakan perintah imread, namun sebelumnya akan melakukan perubahan tipe data citra sidik jari menjadi logical dengan perintah im $2 b w$

$$
\begin{aligned}
& A=i m 2 b w\left(i m r e a d\left(' i b u \_j a r i 1 . j p e g '\right)\right) ; \\
& B=i m 2 b w\left(i m r e a d\left(' i b u \_j a r i 2 . j p e g '\right)\right) ; \\
& C=i m 2 b w\left(i m r e a d\left(' i b u \_j a r i 3 . j p e g '\right)\right) ; \\
& D=i m 2 b w\left(i m r e a d\left(' i b u \_j a r i 4 . j p e g '\right)\right) ; \\
& E=i m 2 b w\left(i m r e a d\left(' i b u \_j a r i 5 . j p e g '\right)\right) ; \\
& F=i m 2 b w\left(i m r e a d\left(' i b u \_j a r i 6 . j p e g '\right)\right) ; \\
& G=i m 2 b w\left(i m r e a d\left(' i b u \_j a r i 7 . j p e g '\right)\right) ; \\
& H=i m 2 b w\left(i m r e a d\left(' i b u \_j a r i 8 . j p e g '\right)\right) ; \\
& I=i m 2 b w\left(i m r e a d\left(' i b u \_j a r i 9 . j p e g '\right)\right) ; \\
& J=i m 2 b w\left(i m r e a d\left(' i b u \_j a r i 10 . j p e g '\right)\right) ;
\end{aligned}
$$

Masing-masing citra asli ibu jari dideklarasikan dengan variabel yang berbeda, dimana untuk citra asli ibu jari1 dideklarasikan dengan variabel A, begitu seterusnya sampai pada citra asli ibu jari10 yang dideklarasikan dengan variabel J. 
Selanjutnya akan dilakukan pendeteksian tepi pada masing-masing citra ibu jari yang menggunakan perintah edge, tiap citra sidik jari akan dilakukan pendeteksian dengan lima metode antara lain

$$
\begin{aligned}
& \text { BW1 = edge(A,'sobel'); } \\
& \text { BW2 = edge(A,'canny'); } \\
& \text { BW3 = edge(A,'prewitt'); } \\
& \text { BW4 = edge(A,'roberts'); } \\
& \text { BW5 = edge(A,'log'); }
\end{aligned}
$$

A adalah variabel untuk citra asli ibu jari1, pendeteksian tepi dengan perintah edge diikuti dengan metode yang digunakan. BW1, BW2, BW3, BW4, dan BW5 adalah deklarasi dari tiap-tiap metode pendeteksian tepi.

Lalu gunakan PSNR untuk menganalisis hasil pendeteksian citra ibu jari, PSNR adalah Peak Signal-to-Noise Ratio yang menghitung dalam decibel $(\mathrm{dB})$ peningkatan kualitas citra hasil pengolahan dengan menggunakan metode pendeteksian tepi dibandingkan dengan citra asli ibu jari yang dapat dilihat pada statement ini

$$
\text { > } \operatorname{psnr}(\mathrm{BW} 1, \mathrm{~A})
$$

PSNR $=+0.55 \mathrm{~dB}$ merupakan nilai yang dihasilkan dari perbandingan antara citra asli ibu jari1 yang dinotasikan dengan variabel A dengan citra hasil pendeteksian tepi dengan metode

Sobel.

$$
\text { > } \operatorname{psnr}(\mathrm{BW} 2, \mathrm{~A})
$$

PSNR $=+0.56 \mathrm{~dB}$ merupakan nilai yang dihasilkan dari perbandingan antara citra asli ibu jaril yang dinotasikan dengan variabel A dengan citra hasil pendeteksian tepi dengan metode

Canny.

$$
\text { > } \operatorname{psnr}(\mathrm{BW} 3, \mathrm{~A})
$$

PSNR $=+0.61 \mathrm{~dB}$ merupakan nilai yang dihasilkan dari perbandingan antara citra asli ibu jari1 yang dinotasikan dengan variabel A dengan citra hasil pendeteksian tepi dengan metode

Prewitt.

$$
\text { > psnr(BW4,A) }
$$

PSNR $=+0.62 \mathrm{~dB}$ merupakan nilai yang dihasilkan dari perbandingan antara citra 
asli ibu jari1 yang dinotasikan dengan variabel A dengan citra hasil pendeteksian tepi dengan metode

Roberts.

$$
\text { > psnr(BW5,A) }
$$

PSNR $=+0.65 \mathrm{~dB}$ merupakan nilai yang dihasilkan dari perbandingan antara citra asli ibu jari1 yang dinotasikan dengan variabel A dengan citra hasil pendeteksian tepi dengan metode Log. Langkah yang sama dilakukan pada citra asli ibu jari2 sampai pada ibu jari10.

\section{Hasil Analisis}

Berdasarkan percobaan yang telah dilakukan terhadap 10 sampel ibu jari, yaitu menggunakan metode pendeteksian tepi antara lain Sobel, Canny, Prewitt, Roberts serta Log didapatkan hasil seperti yang ada pada tabel 3.3.

Tabel 1. Hasil Analisis Deteksi Tepi Citra Sidik Jari

\begin{tabular}{|l|l|l|l|l|l|l|}
\hline Citra Asli & $\begin{array}{l}\text { Metode } \\
\text { Sobel }\end{array}$ & $\begin{array}{l}\text { Metode } \\
\text { Canny }\end{array}$ & $\begin{array}{l}\text { Metode } \\
\text { Prewitt }\end{array}$ & $\begin{array}{l}\text { Metode } \\
\text { Roberts }\end{array}$ & $\begin{array}{l}\text { Metode } \\
\text { Log }\end{array}$ & $\begin{array}{l}\text { Hasil } \\
\text { Terbaik }\end{array}$ \\
\hline ibu jari 1 & $+0.55 \mathrm{~dB}$ & $+0.56 \mathrm{~dB}$ & $+0.61 \mathrm{~dB}$ & $+0.62 \mathrm{~dB}$ & $+0.65 \mathrm{~dB}$ & Sobel \\
\hline ibu jari 2 & $+0.79 \mathrm{~dB}$ & $+0.74 \mathrm{~dB}$ & $+0.81 \mathrm{~dB}$ & $+0.83 \mathrm{~dB}$ & $+0.81 \mathrm{~dB}$ & Canny \\
\hline ibu jari 3 & $+0.88 \mathrm{~dB}$ & $+0.85 \mathrm{~dB}$ & $+0.91 \mathrm{~dB}$ & $+0.92 \mathrm{~dB}$ & $+0.89 \mathrm{~dB}$ & Canny \\
\hline ibu jari 4 & $+0.63 \mathrm{~dB}$ & $+0.64 \mathrm{~dB}$ & $+0.66 \mathrm{~dB}$ & $+0.67 \mathrm{~dB}$ & $+0.78 \mathrm{~dB}$ & Sobel \\
\hline ibu jari 5 & $+0.78 \mathrm{~dB}$ & $+0.73 \mathrm{~dB}$ & $+0.80 \mathrm{~dB}$ & $+0.79 \mathrm{~dB}$ & $+0.74 \mathrm{~dB}$ & Canny \\
\hline ibu jari 6 & $+1.10 \mathrm{~dB}$ & $+1.06 \mathrm{~dB}$ & $+1.14 \mathrm{~dB}$ & $+1.10 \mathrm{~dB}$ & $+1.19 \mathrm{~dB}$ & Canny \\
\hline ibu jari 8 & $+0.76 \mathrm{~dB}$ & $+0.72 \mathrm{db}$ & $+0.79 \mathrm{~dB}$ & $+0.79 \mathrm{~dB}$ & $+0.79 \mathrm{~dB}$ & Canny \\
\hline & & & & & & \\
\hline
\end{tabular}




\begin{tabular}{|l|l|l|l|l|l|l|}
\hline ibu jari 9 & $+0.70 \mathrm{~dB}$ & $+0.66 \mathrm{~dB}$ & $+0.72 \mathrm{~dB}$ & $+0.72 \mathrm{~dB}$ & $+0.71 \mathrm{~dB}$ & Canny \\
\hline ibu jari10 & $+1.01 \mathrm{~dB}$ & $+0.97 \mathrm{~dB}$ & $+1.04 \mathrm{~dB}$ & $+1.04 \mathrm{~dB}$ & $+1.03 \mathrm{~dB}$ & Canny \\
\hline
\end{tabular}

Hasil analisis keseluruhan terhadap $10 \mathrm{ibu}$ jari dari individu yang berbeda dengan metode pendeteksian tepi, didapatkan bahwa metode Sobel menghasilkan nilai terbaik yaitu pada citra hasil pendeteksian di ibu jari 1 dan ibu jari 4. Pada delapan citra lainnya metode Canny memberikan hasil terbaik yaitu dengan nilai terendah, dimana semakin rendah nilai yang dihasilkan dari parameter PSNR, citra hasil pendeteksian metode Canny akan semakin baik. Citra dikatakan semakin baik apabila citra hasil pendeteksian metode Canny menyerupai seperti citra asli ibu jari, sehingga dengan mudah dapat dideteksi. Dengan begitu, akan lebih mudah serta cepat dalam melakukan pendeteksian citra biometrik sidik jari dikarenakan hasil dari citra pendeteksian dengan metode Canny akurat bahkan menyerupai seperti citra asli ibu jari.

\section{KESIMPULAN DAN SARAN}

\section{Kesimpulan}

Dari hasil analisis percobaan yang menggunakan 5 (lima) metodependeteksian tepi yaitu Sobel, Canny, Prewitt, Roberts, serta Log denganmenggunakan perangkat lunak aplikasi Matlab 7.0 dapat disimpulkanbahwa metode Canny adalah metode terbaik. Hasil analisis perbandinganantara 10 citra ibu jari baik yang asli maupun hasil pendeteksian denganparameter PSNR tampak bahwa metode Canny menghasilkan nilaiterendah diantara metode lainnya, dimana semakin rendah nilai hasilperbandingan PSNR, maka semakin baik tingkat penampakannya, yaitucitra hasil pendeteksian dengan metode Canny menyerupai seperti citra ibujari yang asli, sehingga mempermudah serta mempercepat prosespengidentifikasian yang berhubungan dengan citra biometrik ibu jari.

\section{Saran}

Penelitian ini masih jauh dari kesempurnaan, dimungkinkan untukkedepannya tidak hanya dapat menganalisis 5 (lima) metode saja,melainkan dapat membuat perangkat lunak sederhana yang diperlukanuntuk proses pengidentifikasi identitas seseorang. Untuk itu diharapkanperan seluruh pihak yang terkait untuk memperdalam serta memajukansistem biometrika sejak dini agar dapat digunakan di masa yang akandatang. 


\section{REFERENSI}

Ahmad, Usman. (2005). Pengolahan Citra Digital dan Teknik Pemrogramannya. Penerbit Graha Ilmu.

Canny, John. (1986). "A Computational Approach to Edge Detection," IEEE

Transactions on Pattern Analysis and Machine Intelligence. Vol. PAMI-8, No. 6, pp. 679-698.

Hasan, Talib Hashim. (2005). Belajar Sendiri Dasar-Dasar Pemrograman Matlab. Penerbit Gava Media.

Lim, Jae S. (1990), , Two-Dimensional Signal and Image Processing”, Englewood Cliffs, NJ, Prentice Hall, pp. 478-488.

Nugroho, Eko. (2008).BIOMETRIKA Mengenal Sistem Identifikasi Masa Depan. Penerbit Andi.

Putra, Darma. (2009).Sistem Biometrika Konsep Dasar, Teknik Analisis Citra dan Tahapan Membangun Aplikasi Sistem Biometrika. Penerbit Andi.

Sahid, (2006).Panduan Praktis Matlab. Penerbit Andi.

Wijaya, Marvin Ch. \& Agus Prijno. (2007).Pengolahan Citra Digital Menggunakan Matlab. Penerbit Informatika. 